UNITED STATES GEOLOGICAL SURVEY

\title{
MINERAL RESOURCES OF THE \\ CARSON ICEBERG WILDERNESS STUDY AREA, ALPINE COUNTY, CALIFORNIA
}

\author{
B y \\ William J. Keith ${ }^{1}$ \\ U.S. Geological Survey \\ and \\ Michael S. Miller ${ }^{2}$ \\ U.S. Bureau of Mines
}

\section{U.S. Geological Survey \\ Open-File Report 88-273}

Prepared by the U.S. Geological Survey and the U.S. Bureau of Mines
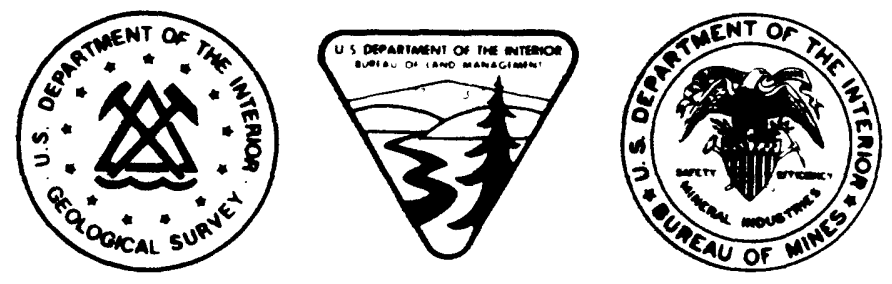

for the U.S. Bureau of Land Management

This report is preliminary and has not been reviewed for conformity with U.S. Geological Survey editorial standards and stratigraphic nomenclature. Any use of trade names is for descriptive purposes only and does not imply endorsement by the U.S. Geological Survey.

${ }^{1}$ Menlo Park, CA 94025

${ }^{3}$ Spokane, WA 99202 


\section{STUDIES RELATED TO WILDERNESS}

\section{Bureau of Land Management Wilderness Study Area}

The Federal Land Policy and Management Act (Public Law 94579, October 21, 1976) requires the U.S. Geological Survey and the U.S. Bureau of Mines to conduct mineral surveys of certain areas to determine the mineral values, if any, that may be present. Results must be made available to the public and be submitted to the President and the Congress. This report presents the results of a mineral survey of the Carson Iceberg Wilderness Study Area (NV-030-532), Alpine County, California. 


\section{CONTENTS}

Summary 1

Abstract 1

Character and setting 1

Identified resources 2

Mineral resource potential 2

Introduction $\mathbf{2}$

Area description 6

Previous and present investigations 6

Acknowledgements 8

Appraisal of identified resources 8

Mining history 8

Alteration sites and alluvium 9

Mineral resources 9

Recommendations 9

Assessment of mineral resource potential 10

Geology 10

Geochemistry 11

Mineral resource potential 12

References cited 12

Appendixes

Definition of levels of mineral resource potential and certainty of assessment 16

Resource/reserve classification $\quad 17$

Geologic time chart 18

Table 1. Altered sites and alluvium from the Carson

Iceberg Wilderness Study Area (NV-030-532) and vicinity, Alpine County, California. 19

Table 2. Analysis of rock samples from the Carson

Iceberg Wilderness Study Area and vicinity, Alpine County, California. 20

Table 3. Free gold content of alluvial samples from the Carson Iceberg Wilderness Study Area and vicinity, Alpine County, California. 21 
Table 4. Analysis of alluvial sample concentrates from the Carson Iceberg Wilderness Study Area and vicinity, Alpine County, California. 22

Figures

1. Index map of the Carson Iceberg Wilderness Study Area, Alpine County, California. 3

2. Mineral resource potential and generalized geologic map of the Carson Iceberg Wilderness Study Area, Alpine County, California. 4 
MINERAL RESOURCES OF THE CARSON ICEBERG WILDERNESS STUDY AREA, ALPINE COUNTY, CALIFORNIA

By William J. Keith

U.S. Geological Survey

Michael S. Miller

U.S. Bureau of Mines

\section{SUMMARY}

\section{Abstract}

At the request of the U.S. Bureau of Land Management, the 550-acre Carson Iceberg Wilderness Study Area (NV-030-532) was studied. In this report, the area studied is referred to as "the wilderness study area," or simply "the study area." The study area is in the central Sierra Nevada Mountains in Alpine County, California. Geological and mineral surveys were conducted by the U.S. Geological Survey and the U.S. Bureau of Mines in 1987 to assess the mineral resources (known) and mineral resource potential (undiscovered) of the study area. No resources were identified in the study area, but the results of these surveys indicate that the area has low resource potential for gold in placer deposits and for silver in epithermal type deposits. An earlier mineral assessment of adjacent lands managed by the U.S. Forest Service collected data on the Carson Iceberg study area but gave no conclusions about the mineral resources and resource potential of this study area.

\section{Character and Setting}

The study area is on the East Fork of the Carson River in the central Sierra Nevada Mountains on the boundary of the Toiyabe 
National Forest about $4.5 \mathrm{mi}$ south of California State Highway 89 (fig. 1). Elevations range from approximately $6,320 \mathrm{ft}$ at the Carson River to $7,120 \mathrm{ft}$ near the southwest corner of the area. The study area is underlain by a thin layer of interbedded lava flows and mudflows of Tertiary age overlying a granitic pluton of Cretaceous age (see appendixes for geologic time chart).

\section{Identified Resources}

The study area has no active mines or claims; one small pit was found. No minable resources were identified. However, uneconomic occurrences of gold, silver, mercury, copper, lead, zinc, and molybdenum (the latter six as background concentrations) were found at seven alteration sites.

\section{Mineral Resource Potential}

The study area has low resource potential for gold (fig. 2.) in placer deposits along the East Fork Carson River; grades are less than .06 grams per metric ton (gm/tonne) (.00175 troy ounces per ton). Over 95 percent of all the placer deposits used to make the grade and tonnage model for placer gold published by Orris and Bliss (1986) have grades higher than this area.

The study area also has low resource potential for epithermal silver in areas near rhyolitic dikes even though detected silver is in or near the background range for silicic dikes (Table 4).

\section{INTRODUCTION}

This mineral survey was requested by the U.S. Bureau of Land Management and is the result of a cooperative effort by the U.S. Geological Survey and the U.S. Bureau of Mines. An introduction to the wilderness review process, mineral survey methods, and agency responsibilities were provided by Beikman and others, (1983). The U.S. Bureau of Mines evaluates identified resources at individual mines and known mineralized areas by collecting data on current 


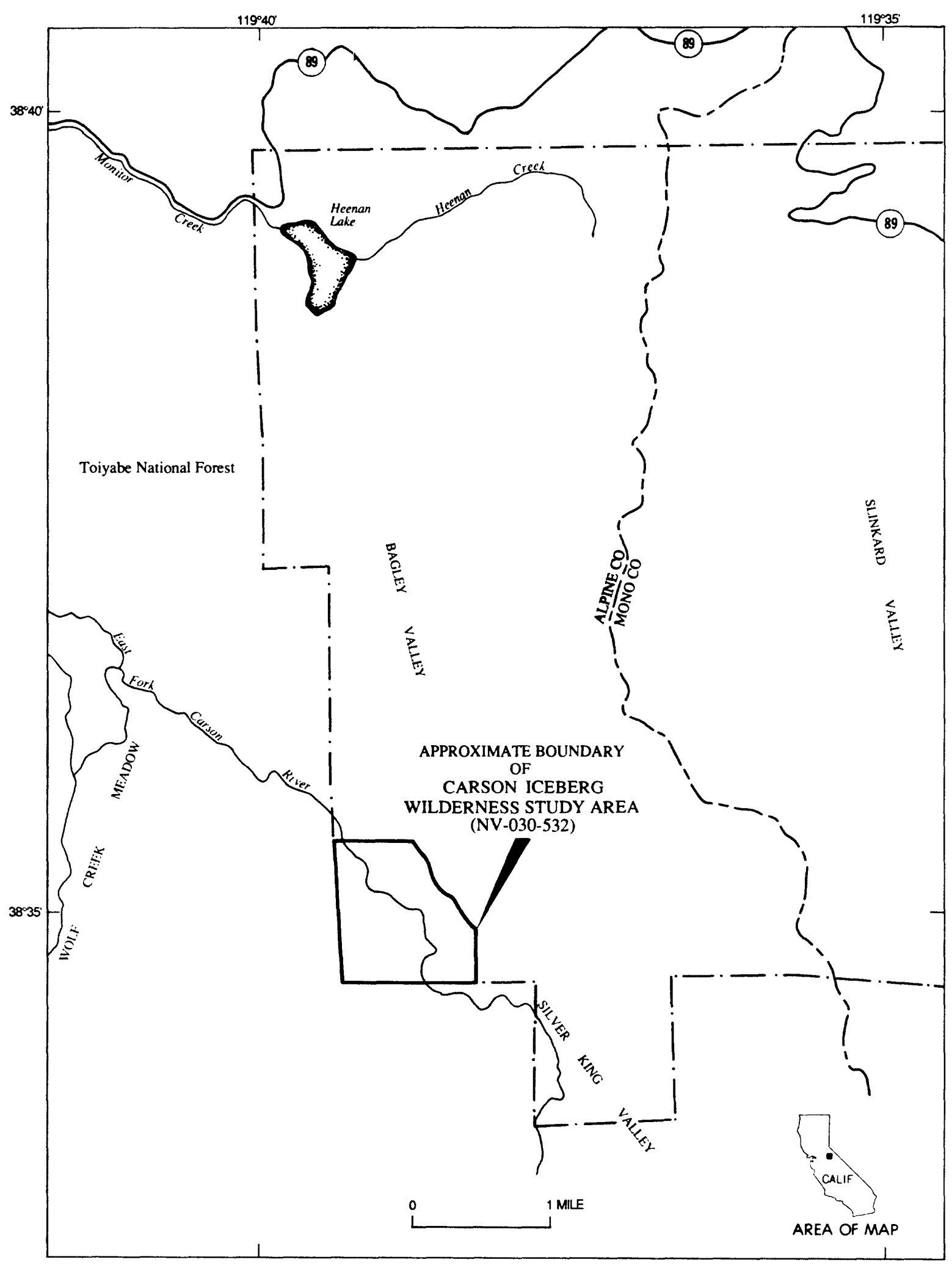

Figure 1. Index map of the Carson Iceberg Wilderness Study Area, Alpine County, California. 


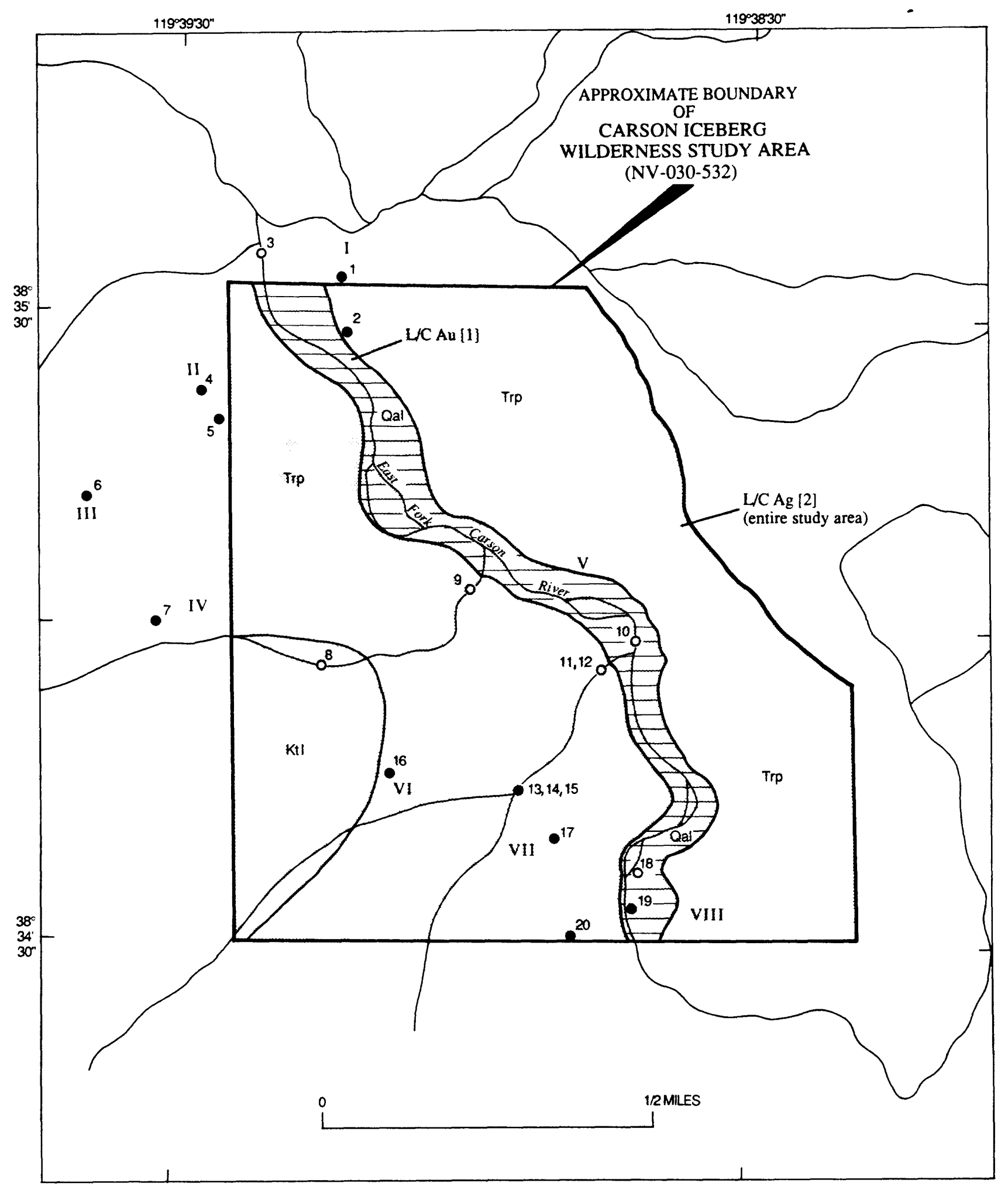

Figure 2. Mineral resource potential and generalized geologic map of the Carson Iceberg Wilderness Study Area, Alpine County, California. 


\section{EXPLANATION}

Area with low mineral resource potential (L)

C Certainty level of assessment-Data give

good indication of level of potential

Commodities

Au Gold

Ag Silver

[ ] Type of deposit or occurrence

1 Placer

2 Disseminated epithermal

Geologic map units

Qal Alluvium (Quaternary)-Unconsolidated silt, sand, and gravel

Trp Relief Peak Formation (Tertiary)Interbedded andesitic lava flows, lahars, and sedimentary rocks

Ktl Granodiorite of Topaz Lake (Cretaceous)Coarsely prophyritic granodiorite

Contact

Rock sample location (see table 2 , appendixes)

$0^{3} \quad$ Alluvium sample location (see tables 3 and 4, appendixes)

IV Site location-May cover large area and contain more than one sample locality (see table 1, appendixes)

Figure 2. Continued 
and past mining activities and through field examination of mines, prospects, claims, and mineralized areas. Identified resources are. classified according to a system that is a modification of that described by Mckelvey (1972) and U.S. Bureau of Mines and U.S. Geological Survey (1980). U.S. Geological Survey studies are designed to provide a scientific basis for assessing the potential for undiscovered mineral resources by determining geologic units and structures, possible environments of mineral deposition, presence of geochemical and geophysical anomalies, and applicable ore-deposit models. Goudarzi (1984) discussed mineral assessment methodology and terminology as they apply to these surveys. See the appendixes for the definition of levels of mineral resource potential and certainty of assessment and for the resource/reserve classification.

\section{Area Description}

At the request of the U.S. Bureau of Land Management, 550acre Carson Iceberg Wilderness Study Area (NV-030-532) was studied. The study area consists of forested slopes and perennial streams and is located in the central Sierra Nevada mountains, northeastern Alpine County, California (fig. 1). It is accessible by foot and horse trails. Elevations range from approximately $6,320 \mathrm{ft}$ at the Carson River to $7,120 \mathrm{ft}$ near the southwest corner.

\section{Previous and Present Investigations}

A mineral resource potential evaluation of the contiguous Carson-Iceberg and Leavitt Lake Roadless Areas by the U.S. Geological Survey and the U.S. Bureau of Mines was published in 1983 (Keith and others, 1983). During that study, the U.S. Geological Survey collected and analyzed 131 rock samples, 220 streamsediment samples screened at minus $0.25 \mathrm{~mm}$, and 221 nonmagnetic heavy-mineral-concentrate samples. All of the samples were analyzed for 31 elements by the emission spectrograph method. In addition, the rock and stream-sediment samples were analyzed for bismuth, cadmium, antimony, and zinc by atomic-absorption 
spectrometry and arsenic by a colorimetric method. Statistical analyses were run on the results to determine which concentrations were background and which were anomalous (Sutley and others, 1982). Regional gravity (Plouff, 1982, 1987a) and aeromagnetic surveys (Plouff, 1987b) were compiled and analyzed. The geology of the area was mapped and published at a scale of 1:62,000.(Keith and others, 1982). Data from this earlier study includes the Carson Iceberg Wilderness Study Area, and was therefore used in the present study in conjunction with field checking of the site by U.S. Geological Survey personnel.

The U.S. Bureau of Mines investigation was conducted by personnel from the Western Field Operations Center (WFOC), Spokane, Washington, during 1986 and 1987, and consisted of office and library research, followed by field work and report preparation. Prefield studies included a literature search and an examination of Alpine County and U.S. Bureau of Land Management mining claim and mineral lease records. U.S. Bureau of Mines production records also were examined. Field studies included a search for alteration sites containing silica, clay, and iron oxides (siliceous, argillic, and limonitic alteration) within the wilderness study area. Alteration sites were examined, and, if warranted, were mapped and sampled. Alteration sites close to the study area also were examined to determine if they extended into the area, and to better understand mineralization in the region.

Ten rock and 10 stream sediment samples were taken. Rock samples were of three types: (1) chip - contiguous rock fragments generally collected in a continuous line across an alteration zone; (2) random chip - randomly located rock fragments taken from an altered outcrop; (3) grab - rock pieces or soil taken more or less at random from float (loose rock on the ground), or other loose material. All stream sediment samples consisted of surficial sand and gravel.

Rock samples were crushed, pulverized, and split at WFOC. Splits were sent to commercial laboratories for analysis by inductively coupled plasma emission spectroscopy.

All stream sediment samples were partially concentrated by panning or sluicing in the field, and were further concentrated on a 
laboratory-size Wilfley table. Resulting heavy-mineral fractions were examined with a binocular microscope for gold and other valuable minerals. When visable gold was detected, as in five of the ten samples, larger particles were hand-picked and weighed along with fine gold recovered by amalgamation.

Splits and concentrates were checked for radioactivity and fluorescence in the preparation laboratory. Stream sediment sample concentrates were sent to commercial laboratories for analysis by induced neutron activation analysis and $x$-ray fluorescence.

A Geometrics model GR-101A scintillometer was used for field radiometric measurements. Nothing unusual was detected. Readings were from 20 to 90 counts per second.

\section{Acknowledgments}

Messrs. Terry J. Close, William Hale, Richard A. Winters, Thomas J. Peters and Terry Neumann assisted the U.S. Bureau of Mines in the field. Logistical support of the U.S. Bureau of Land Management is gratefully acknowledged.

\section{APPRAISAL OF IDENTIFIED RESOURCES}

By Michael S. Miller

U.S. Bureau of Mines

\section{Mining History}

Mining districts and claims were mapped in the Carson Iceberg area by Reed (unpublished maps, 1864, 1866). The study area is at the east side of the Silver Mountain district and at the west side of the Silver King district. The Monitor and Mogul districts are located 5 and $20 \mathrm{mi}$ to the north (Reed, unpublished maps, 1864, 1866).

Prospecting began in the 1850's, and by the 1860's the Silver Mountain, Monitor, and Mogul districts were producing silver and gold. Although figures are incomplete, $\$ 300,000$ may have been produced from the Silver Mountain district (Clark, 1977, p. 28). 
No mines or mining claims are currently active in the study area, although one small pit was found. No geothermal energy or oil and gas leases are known. The nearest mine with resources of metallic minerals is the Log Cabin (Dixon) mine about $2 \mathrm{mi}$ northwest of the study area. This mine was estimated to have 900,000 tons of indicated marginal reserves with grades of 0.1 to $0.4 \mathrm{oz}$ gold per ton (Keith and others, 1983).

\section{Alteration Sites and Alluvium}

Information about the seven alteration sites and alluvium is summarized in table 1; location of the sites and sample localities are shown on fig. 1.

\section{Mineral Resources}

Study area alluvium along the East Fork Carson River and two of its tributaries contains uneconomic gold. Argillic, silicic, and limonitic sites throughout the study area contain uneconomic amounts of silver, copper, lead, zinc, mercury, arsenic, and molybdenum. All metal concentrations are 20 percent or less of those at a typical economically minable deposit. Therefore, the likelihood of the sites becoming minable in the future is small. Stone and sand and gravel occurrences were not evaluated for construction material or for other building purposes because of their small size and distance to existing markets.

\section{Recommendations}

Additional work is not recommended at the present because the metal concentrations detected were many times smaller than currently being mined. However, if the Carson Iceberg Wilderness Study Area were ever investigated in more detail, mapping and geochemical sampling could be used to search for metal deposits. Targets include small, high-grade deposits of silver along or near argillic volcanic rocks (fig. 2 , sample nos. $4,5,17,20$ ) trending from 
the south-central part of the study area to the northwest corner. The granitic rocks (fig. 2, sample no. 7) in the west and northwest part of the area may be a target for molybdenum, silver, and gold exploration.

\section{ASSESSMENT OF MINERAL RESOURCE POTENTIAL}

By William J. Keith

U.S. Geological Survey

\section{Geology}

The study area is in the central part of the Sierra Nevada Mountains, and is situated $8 \mathrm{mi}$ northeast of the range crest. It consists of a thin accumulation of interbedded lava flows and mudflows of Tertiary age (Relief Peak Formation of Slemmons, 1966) which overlies a granitic pluton of Cretaceous age (Granodiorite of Topaz Lake, Curtis, 1951; Slemmons, 1953). Locally, both of these units have been intruded by younger rhyolitic dikes.

The Relief Peak Formation is composed of a series of interbedded andesitic flows, lahars, massive conglomerate beds and fine-grained sediments. Many of the andesite flows are autobrecciated and boulders in the conglomerates are as much as $5 \mathrm{ft}$ in diameter. The unit is locally bleached and oxidized along joints and shear zones.

The Granodiorite of Topaz Lake is composed of large (2 to 4 in. long) microcline perthite phenocrysts set in a groundmass of microcline, plagioclase, biotite, and relatively large sphene. Locally, the unit contains aplite and pegmatite dikes along the intrusive contacts.

The rhyolitic rocks that intrude the Relief Peak Formation and Granodiorite of Topaz Lake consist of white, green, orange, and gray aphanitic to porphyritic rocks that range from rhyolite to dacite in composition. These dikes are too small to map and occur sporadically throughout the area. Phenocrysts in these rocks include variable amounts of biotite, hornblende, augite, plagioclase, sanidine, and 
quartz generally set in a glassy groundmass. Some of these dikes show small alteration halos up to 3 or $4 \mathrm{ft}$ wide.

\section{Geochemistry}

Geochemical data were obtained from a regional geochemical study by the U.S. Geological Survey (Sutley and others, 1982) and from rock and placer samples collected by the U.S. Bureau of Mines (table 2). These data identify local areas of alteration.

Background geochemical values for various elements in the units of the study area are high (Sutley and others, 1982). Copper ranges from 5 to 50 parts per million (ppm) in the Relief Peak Formation (hereafter known as the mudflows) and averages 22.7 ppm. In the Granodiorite of Topaz Lake (hereafter known as the granodiorite), copper ranges from 5 to $70 \mathrm{ppm}$ but the average is approximately $40 \mathrm{ppm}$. Lead in the mudflows ranges from 10 to 70 $\mathrm{ppm}$ with an average of $29 \mathrm{ppm}$; in the granodiorite it ranges from 20 to $100 \mathrm{ppm}$ with an average of about $50 \mathrm{ppm}$. Zinc ranges from 20 to $85 \mathrm{ppm}$ in the mudflows and has an average of about $49 \mathrm{ppm}$. In the granodiorite, zinc ranges from 10 to $80 \mathrm{ppm}$ and averages about $48 \mathrm{ppm}$. Antimony in the granodiorite ranges from less than 1 to $2 \mathrm{ppm}$ with an average of about $1.2 \mathrm{ppm}$. The antimony in the mudflows ranges from less than 1 to $5 \mathrm{ppm}$ with an average of about $1.4 \mathrm{ppm}$. Background values for mercury, molybdenum, and silver are not available for rocks in this area but estimated abundances for rocks similar to those in this area (Parker, 1967, table 19) indicate that the concentrations in the study area samples (table 2) represent either background values or small concentrations above background. Uranium occurs sporadically in the gravels near the base of the Relief Peak Formation and is sometimes concentrated in the Quaternary alluvium. Uranium and thorium in the study area are found in sphene from the Topaz Lake Pluton and are likewise concentrated in streambeds. This is probably the source of the uranium and thorium found in nonmagnetic heavy-mineral concentrates from the area (Table 4). Most of the arsenic concentrations for the samples shown in table 2 are below the detection limit $(10 \mathrm{ppm})$ in the Sutley study 
(1982). However, samples 2, 6, and 7, have higher concentrations than one would expect and probably represent minor leaching type. alteration.

\section{Mineral Resource Potential}

The study area has low resource potential (certainty level C) for gold in placer deposits, which have a grade of less than .06 $\mathrm{gm} /$ tonne (.00175 troy ounces per ton). Gold occurs in stream gravels in the Carson River and some of its tributaries but the grade is extremely low. More than 95 percent of the placers used to make up a placer gold grade and tonnage model published by Orris and Bliss (1986) are higher in grade, and would require processing large tonnages of gravel (Bliss and others, 1987). However, large quantities of gravel do not exist in the study area, and thus the gold resource potential is low.

The remainder of the area has low resource potential (certainty level C) for silver in epithermal deposits. The copper, lead, zinc, mercury, molybdenum, and silver concentrations found in the area probably represent background concentrations of these elements and therefore they should not be used as pathfinder elements. However, since alteration areas do exist in the study area, the resource potential for silver has to be low as opposed to no potential. The absence of vein systems, stockworks, or extensive hydrothermal areas indicate that any epithermal silver deposits in this area would be much smaller than any of those listed in the epithermal goldsilver ore deposit models of Cox and Singer (1986).

\section{REFERENCES CITED}

Beikman, H.M., Hinkle, M.E., Frieders, Twila, Marcus, S.M., and Edward, J.R.,1983, Mineral surveys by the Geological Survey and the Bureau of Mines of Bureau of Land Management Wilderness Study Areas: U.S. Geological Survey Circular 901, 28 p. 
Bliss, J.D., Orris, G.J., and Menzie, W.D., 1987, Changes in grade, volume and contained gold during the mining life-cycle of gold placer deposits: Canadian Mining and Metallurgical Bulletin, vol. 80 , no. 903 , p. $75-80$.

Clark, W.B., 1977, Mines and mineral resources of Alpine County, California,with sections on the Zaca gold-silver mine and the Leviathan sulfur mine by James R. Evans: California Division of Mines and Geology County Report 8, 48 p.

Cox, D.P., and Singer, D.A., eds., 1986, Mineral deposit models: U.S.Geological Survey Bulletin 1693, 379 p.

Curtis, G.H., 1951, The geology of the Topaz Lake quadrangle and the eastern half of Ebbetts Pass quadrangle: Berkeley, University of California, Ph.D thesis, 310 p.

Goudarzi, G.H., 1984, Guide to preparation of mineral survey reports on public lands: U.S. Geological Survey Open-File Report 84787, $51 \mathrm{p}$.

Keith, W.J., Dohrenwend, J.C., Giusso, J.R., and John, D.A., 1982, Geologic Map of the Carson-Iceberg and Leavitt Lake Roadless Areas, Central Sierra Nevada, California: U.S. Geological Survey Miscellaneous Field Studies Map MF-1416-A, scale 1:62,500.

Keith, W.J., Chaffee, M.A., Plouff, Donald, and Miller, M.S., 1983, Mineral Resource potential of the Carson-Iceberg Roadless areas, central Sierra Nevada, California: U.S. Geological Survey Miscellaneous Field Studies Map MF-1416-B, scale 1:62,500.

McKelvey, V.E., 1972, Mineral resourceestimates and public policy: American Scientist, v. 60 , p. $32-40$.

Orris, G.J., and Bliss, J.D., 1986, Grade and tonnage model of placer Au-PGE, in Cox, D.P., and Singer, D.A., eds., Mineral deposit models: U.S. Geological Survey Bulletin 1693, p. 261-262.

Parker, R.L., 1967, Composition of the earth's crust: U.S. Geological Survey Professional Paper 440-D, p. D1-D19.

Plouff, Donald, 1982, Gravity observations in the Walker Lake $1^{\circ}$ by $2^{\circ}$ quadrangle, California-Nevada: U.S. Geological Survey OpenFile Report 82-405, 105 p. 
1987a, Bouguer gravity anomaly and isostatic residual gravity maps of the Walker Lake $1^{\circ}$ by $2^{\circ}$ quadrangle, California and Nevada: U.S. Geological Survey Miscellaneous Field Studies Map MF-1382-E, 2 sheets, scale 1:250,000.

1987b, Maps showing aeromagnetic intensity, flight altitudes, and generalized aeromagnetic intensity of the Walker Lake $1^{\circ}$ by $2^{\circ}$ quadrangle, California and Nevada: U.S. Geological Survey Miscellaneous Field Studies Map MF-1382-F, 3 sheets, scale $1: 250,000$.

Slemmons, D.B., 1953, Geology of the Sonora Pass region: Berkeley, University of California, Ph. D. thesis, $201 \mathrm{p}$.

1966, Cenozoic volcanism of the central Sierra Nevada, California: California Division of Mines and Geology Bulletin 190, p. 199-208.

Sutley, S.J., Chaffee, M.A., Fey, D.L., Hill, R.H., and Speckman, W.S., 1982, Chemical analyses and statistical summaries for samples of rock, minus-60-mesh $(0.25-\mathrm{mm})$ stream sediment, and nonmagnetic heavy-mineral concentrate, Carson-Iceberg and Leavitt Lake Roadless Areas, Alpine, Mono, and Tuolumne Counties, California: U.S. Geological Survey Open-File Report 82-954, 50 p.

U.S. Bureau of Mines and U.S. Geological Survey, 1980, Principles of a resource/reserve classification for minerals: U.S. Geological Survey Circular 831, 5 p. 
APPENDIXES 


\section{DEFINITION OF LEVELS OF MINERAL RESOURCE POTENTIAL AND CERTAINTY OF ASSESSMENT}

LOW mineral resource potential is assigned to areas where geologic, geochemical, and geophysical characteristics define a geologic environment in which the existence of resources is permissive. This broad category embraces areas with dispersed but insignificantly mineralized rock as well as areas with few or no indications of having been mineralized.

MODERATE mineral resource potential is assigned to areas where geologic, geochemical, and geophysical characteristics indicate a geologic environment favorable for resource occurrence, where interpretations of data indicate reasonable likelihood of resource accumulation, and (or) where an application of mineral-deposit models indicates favorable ground for the specified type(s) of deposits.

HIGH mineral resource potential is assigned to areas where geologic, geochemical, and geophysical characteristics indicate a geologic environment favorable for resource occurence, where interpretations of data indicate a high degree of likelihood for resource accumulation, where data supports mineral-deposit models indicating presence of resources, and where evidence indicates that mineral concentration has taken place. Assignment of high resource potential to an area requires some positive knowledge that mineral-forming processes have been active in at least part of the area.

UNKNOWN mineral resource potential is assigned to areas where information is inadequate to assign low, moderate, or high levels of resource potential.

NO mineral resource potential is a category reserved for a specific type of resource in a well-defined area.

\section{Levels of Certainty}

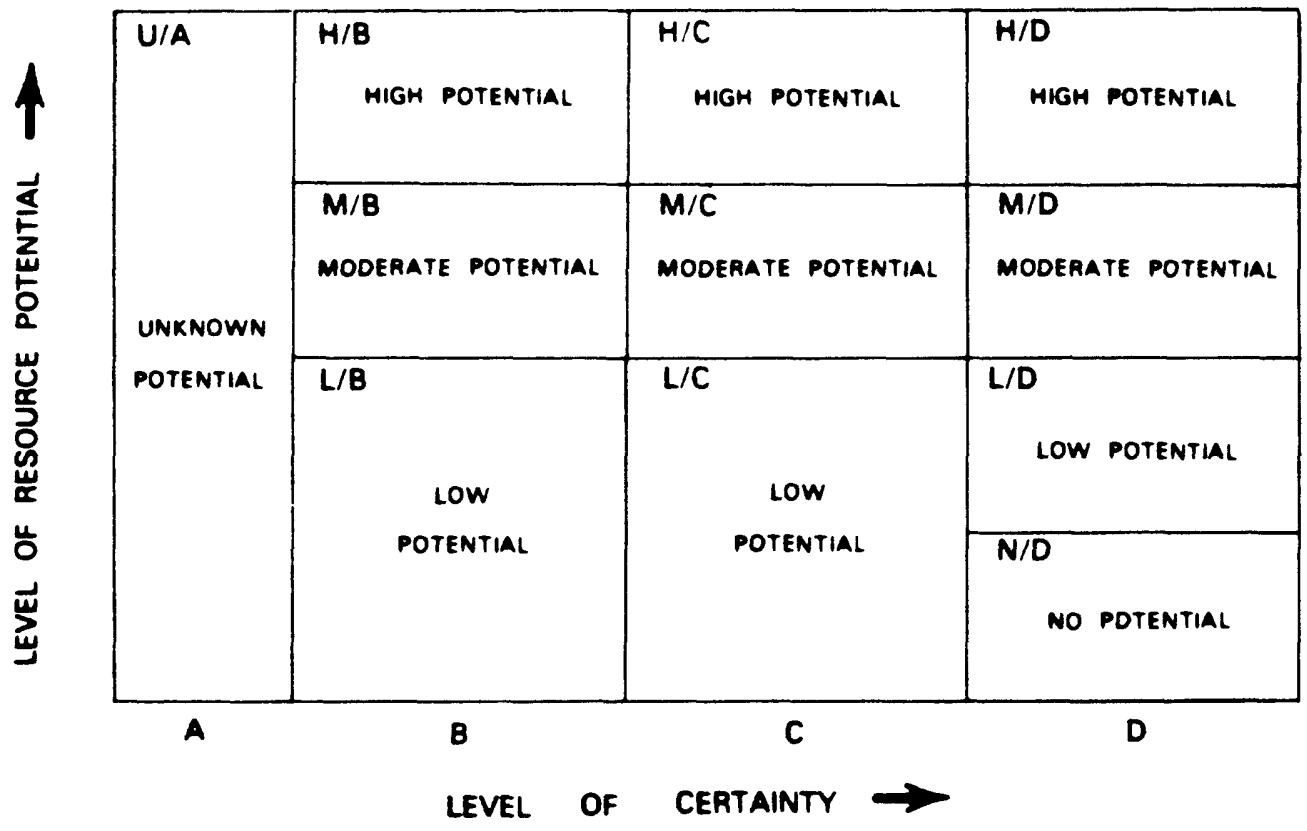

A. Available information is not adequate for determination of the level of mineral resource porential.

B. Available information suggests the level of mineral resource potential.

C. Available information gives a good indication of the level of mineral resource potential

D. Available information clearly defines the level of mineral resource potential

\section{Abstracted with minor modifications from:}

Taylor, R. B., and Steven, T. A.. 1983, Definition of mineral resource potential: Economic Geology. v. 78, no. 6. p. $1268-1270$.

Taylor, R. B., Stoneman, R. J., and Marsh, S. P., 1984. An assessment of the mineral resource potential of the San Isabel National Forest, south-central Colorado: U.S. Geological Survey Bulletin 1638, p. 40-42.

Goudarzi, G. H., compiler, 1984, Guide to preparation of mineral survey repons on poblic lands: U.S. Geological Survey Open-File Repon 84-0787. p 7. 8 


\section{RESOURCE/RESERVE CLASSIFICATION}

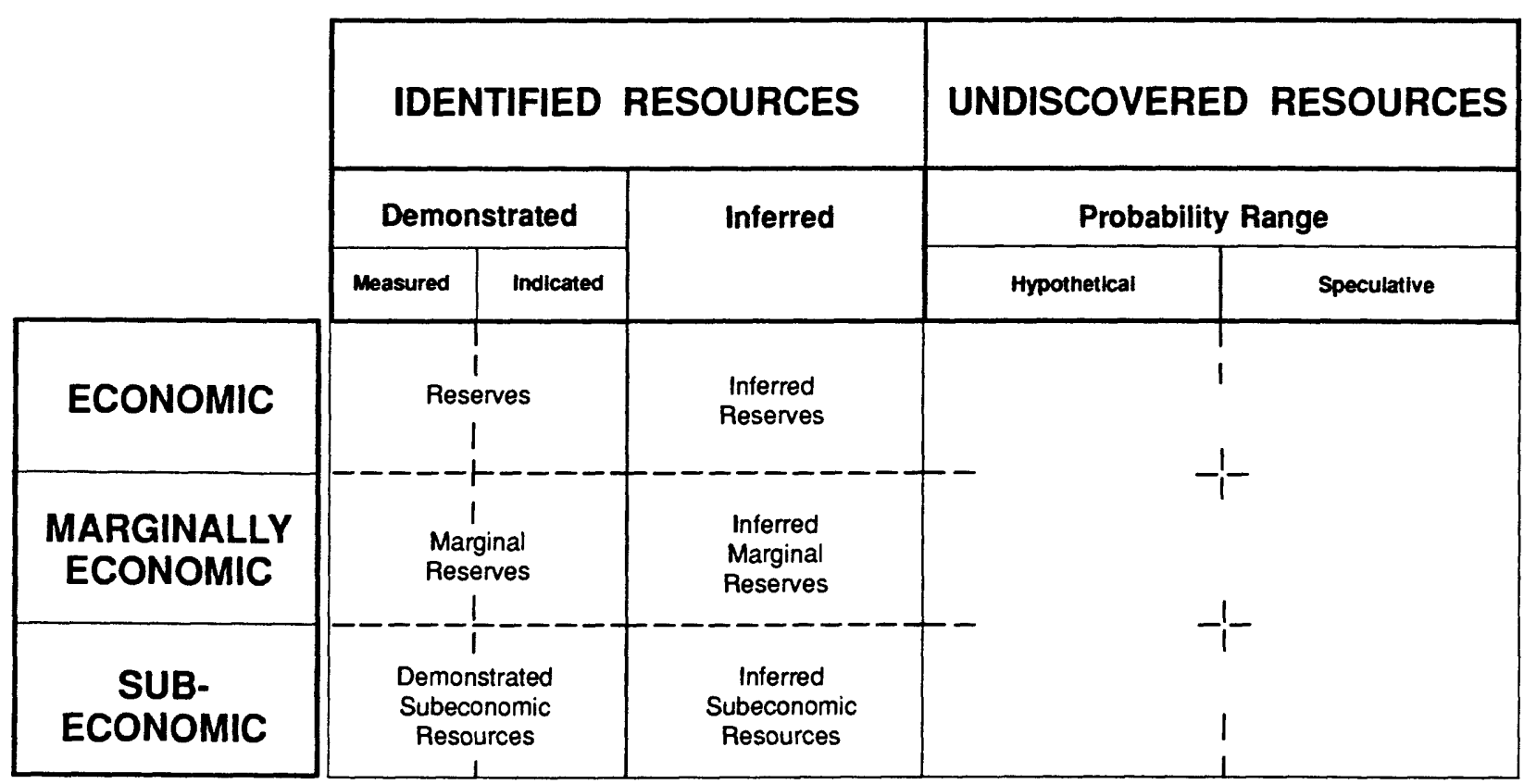

Major elements of mineral resource classification, excluding reserve base and inferred reserve base. Modified from U.S. Bureau of Mines and U.S. Geological Survey, 1980, Principles of a resource/reserve classification for minerals: U.S. Geological Survey Circular 831 , p. 5. 
GEOLOGIC TIME CHART

Terms and boundary ages used by the U.S. Geological Survey in this report

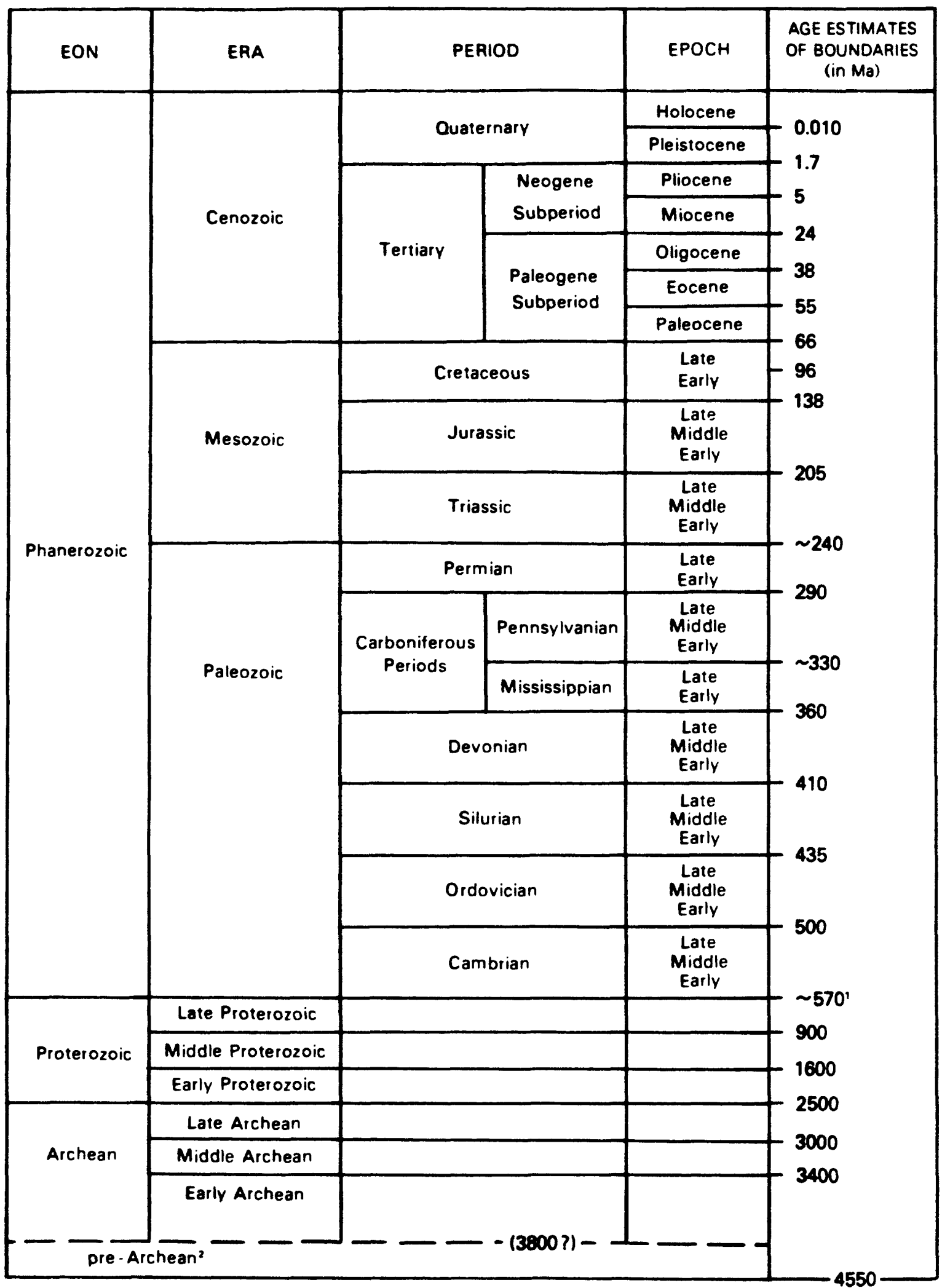

'Rocks older than 570 Ma also called Precambrian, a time term without specific rank.

Informal time term without specific renk. 


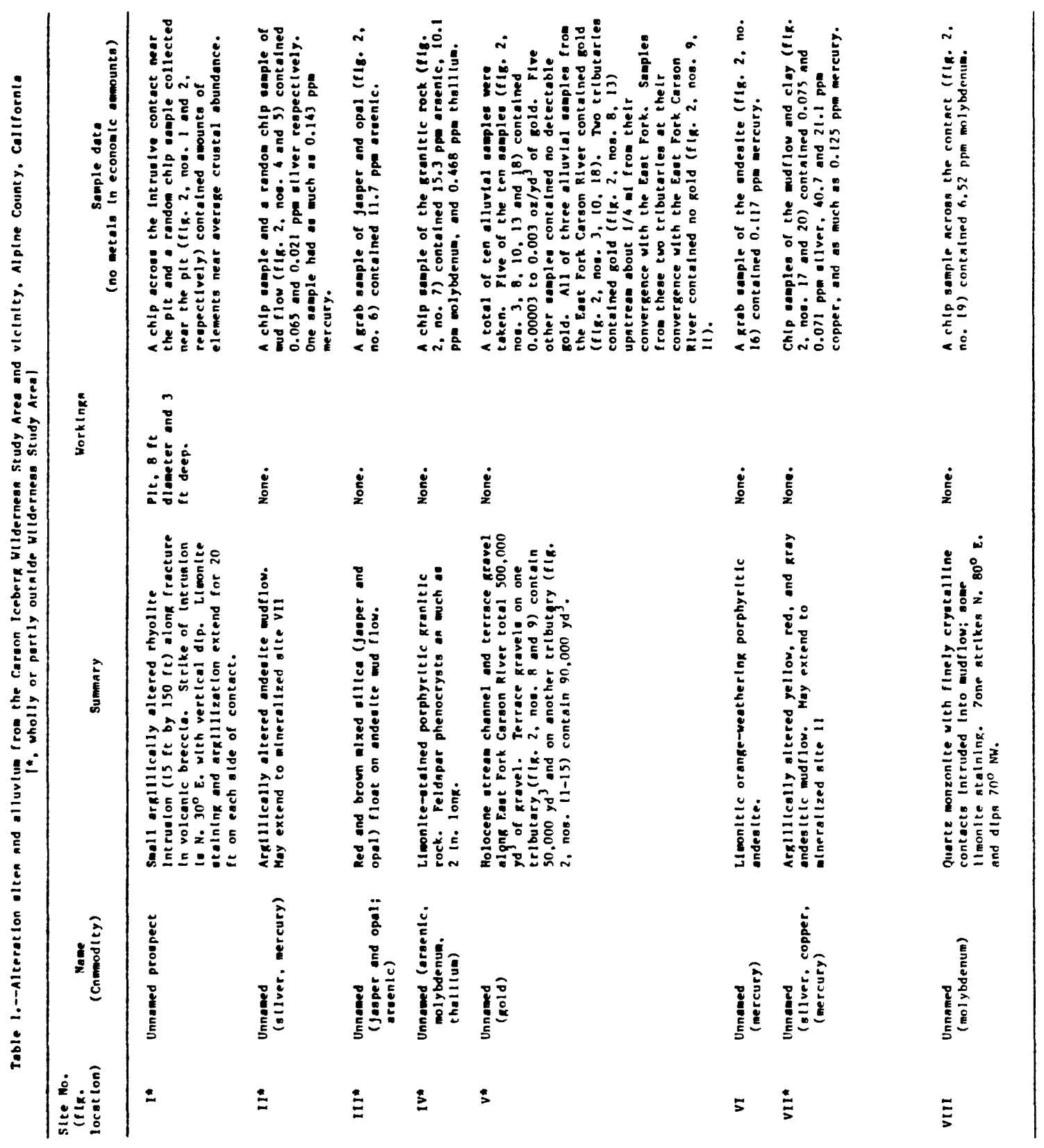




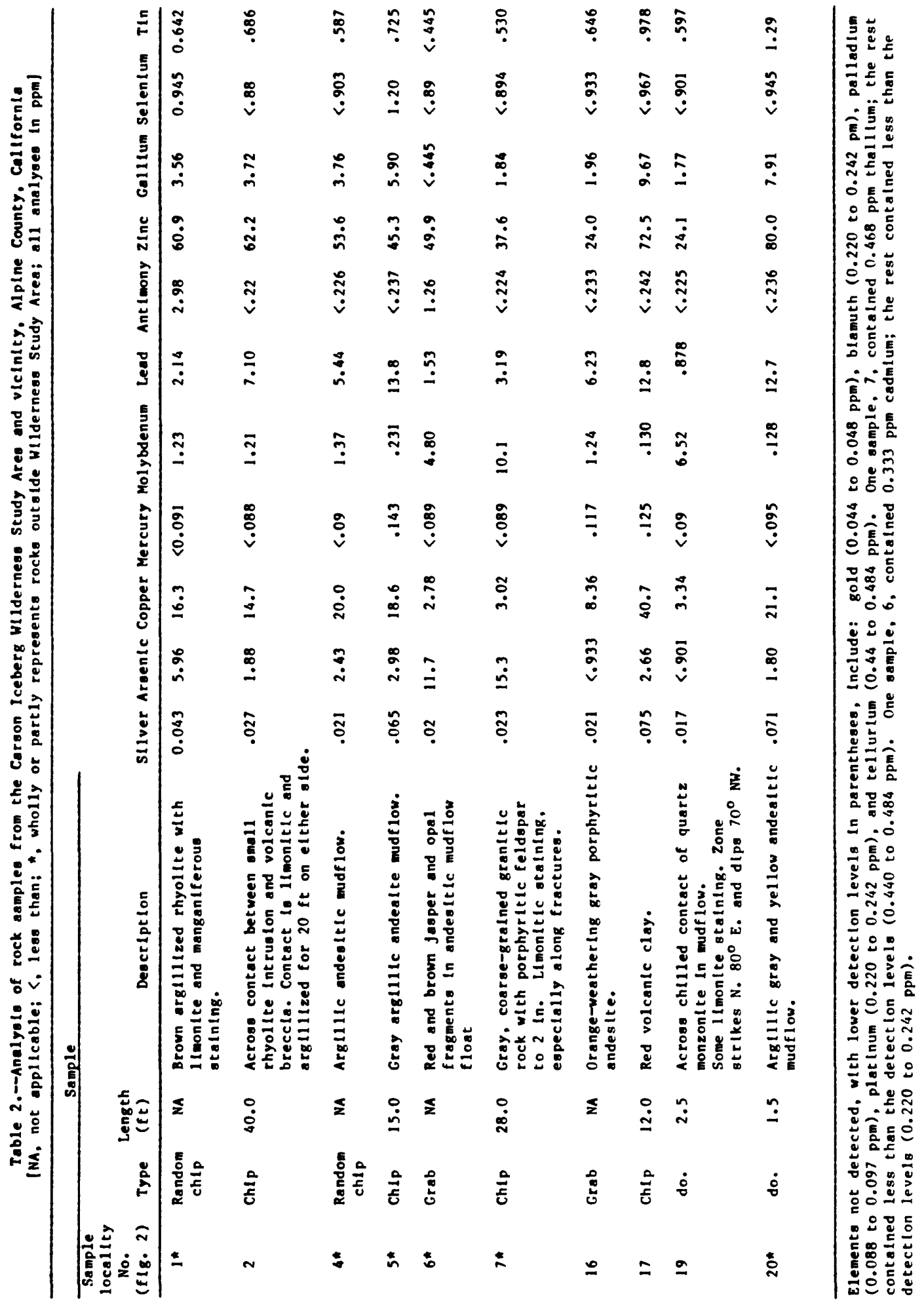


Table 3.-Free gold content of alluvial samples frow the Carson Iceberg Wilderness Study Area and viclnity, Alplne County, Callfornia

[*, wholly or partly outside wilderness study srea]

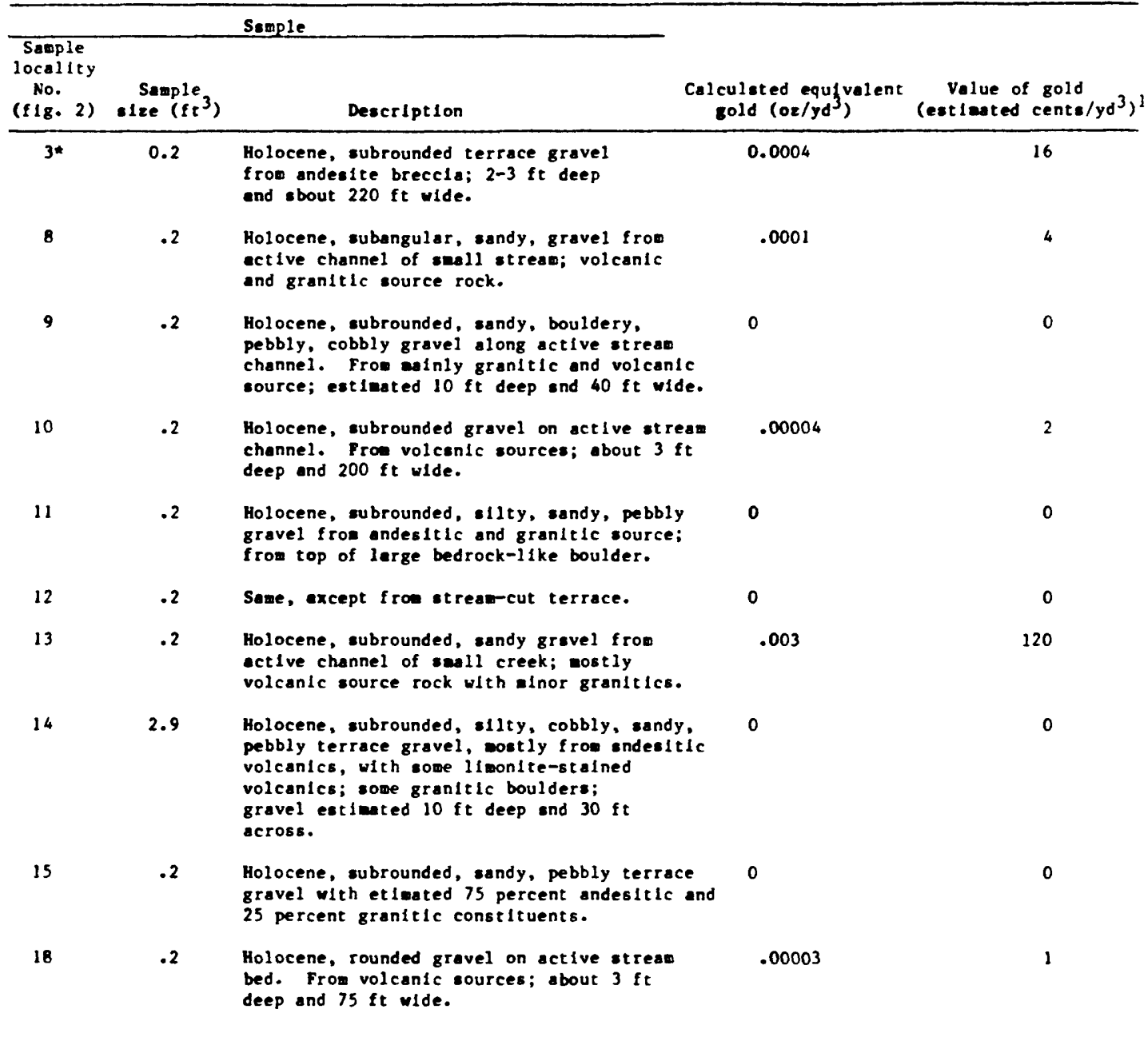

${ }^{1}$ Gold price $\$ 400 / t$ roy ounce; gravel essumed to expand 25 percent on excavation; gold assumed 1,000 flne. 


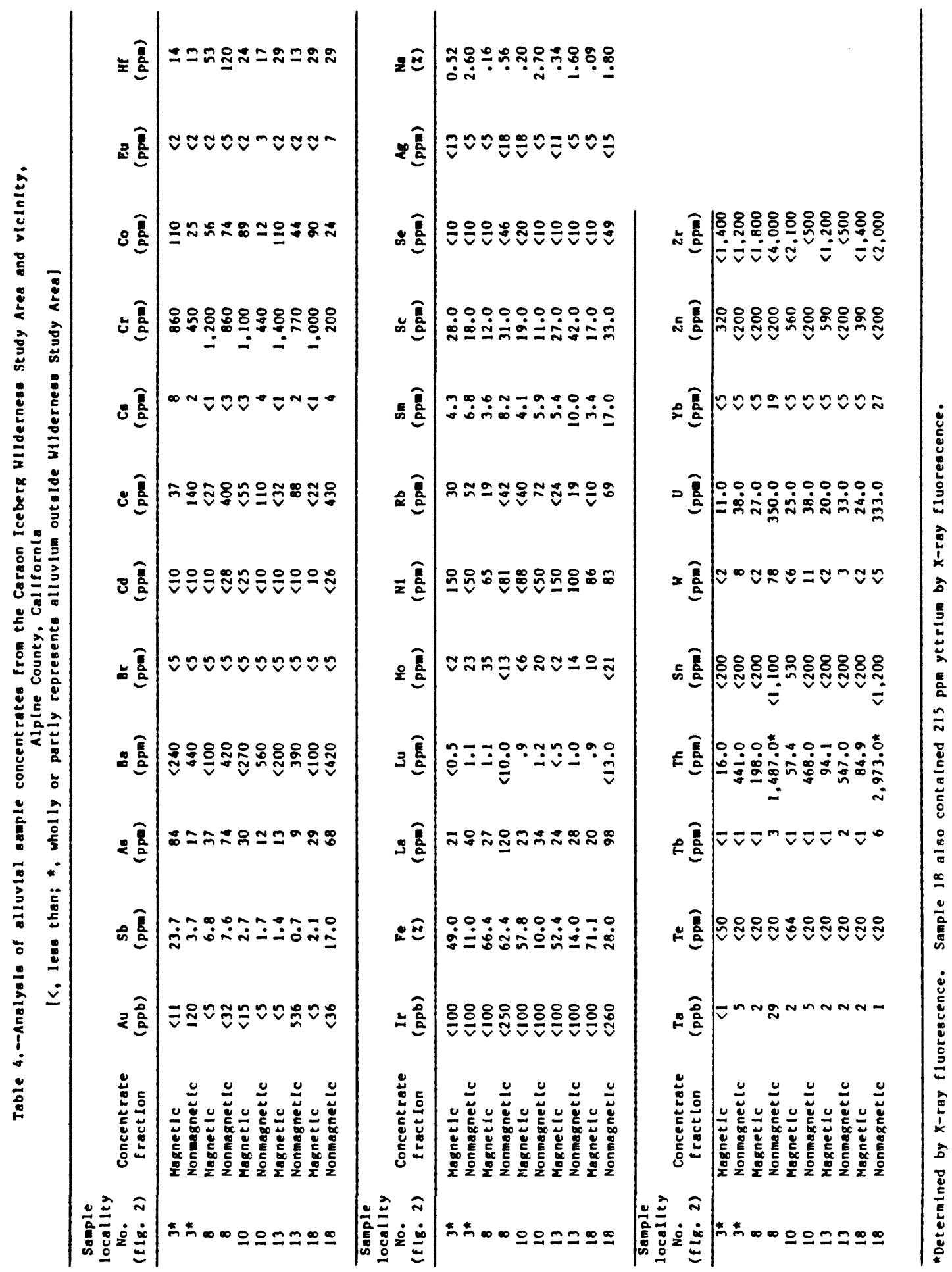

